\title{
Reflecting critically on the researcher-participant encounter in focus groups: Racialized interactions, contestations and (re)presentations of South Africa's "protest culture"
}

Josephine Cornell, Nick Malherbe, Shahnaaz Suffla \& Mohamed Seedat

To cite this article: Josephine Cornell, Nick Malherbe, Shahnaaz Suffla \& Mohamed Seedat (2019): Reflecting critically on the researcher-participant encounter in focus groups: Racialized interactions, contestations and (re)presentations of South Africa's "protest culture", Qualitative Research in Psychology, DOI: 10.1080/14780887.2019.1577519

To link to this article: https://doi.org/10.1080/14780887.2019.1577519

Published online: 16 Feb 2019.

Submit your article to this journal एँ

View Crossmark data ¿ 


\title{
Reflecting critically on the researcher-participant encounter in focus groups: Racialized interactions, contestations and (re)presentations of South Africa's "protest culture"
}

\author{
Josephine Cornell $\mathbb{1}^{\mathrm{a}, \mathrm{b}}$, Nick Malherbe $\mathbb{1}^{\mathrm{b}, \mathrm{a}}$, Shahnaaz Suffla $\mathbb{1}^{\mathrm{a}, \mathrm{b}}$, \\ and Mohamed Seedat $\mathbb{1}^{\mathrm{b}, \mathrm{a}}$ \\ aSouth African Medical Research Council-University of South Africa Violence, Injury and Peace Research \\ Unit, Francie van Zijl Drive, Parowvallei, Cape Town, South Africa; 'bnstitute for Social and Health \\ Sciences, University of South Africa, Johannesburg, South Africa
}

\begin{abstract}
South Africa has a considerable history of public protest from which a contemporary "culture of protest" has emerged. Despite the wide-ranging body of research on protest in South Africa, few studies have considered critically the discursive space in which researchers and participants are embedded. In this article, we use discursive psychology to examine reflexively how South African protesters discursively contest, (re)produce, and negotiate South Africa's culture of protest in the presence of their comrades and researchers. Our analysis focuses on the making of "protest culture," discursive resistance in the research setting, and the effect of researcher silence. We conclude by calling for protest researchers to remain sensitive to power differentials operating in research settings, while establishing a discursive space within these settings wherein participants feel heard and researchers do not attempt to mute their presence to achieve "neutrality".
\end{abstract}

\section{KEYWORDS}

Critical reflexivity; discursive psychology; focus groups; culture of protest; protest violence; South Africa

Numerous academic, popular, and political actors proclaim that South Africa exhibits a "culture of protest" (see Bruce 2014; Kotze \& Taylor 2010; Montse 2017; Laganparsad 2016; Petrus \& Isaacs-Martin 2011) to which violence, understood here in direct and relatedly structural formations (see Galtung 1969), is central. Certainly, protest action in contemporary South Africa should not be interpreted as new, sporadic, sudden, and/or without organic origin, as it so often is in mainstream media (Duncan 2016; Robins 2014). Instead, we need to read such popular resistance against the centuries of protest that preceded and continue to inform it (see James 2012) as well as in relation to a local-global nexus of struggle. In this regard, protest is not an external object acting onto history. Rather, it was and continues to be an inextricable facet in the shaping of South African society and the freedoms which have been (and are yet to be) 
formalized. In short, protest is a form of history, and thus it is an important source of cultural identity for many South Africans.

In what follows, we endeavor not to offer an analysis of "protest culture" per se. Instead, by reflecting critically on a focus group discussion on protest, we focus on how protesters discursively contest, (re)produce, and negotiate protest culture in the presence of researchers. We examine power in this researcher-participant discursive interaction, both in how we as researchers inadvertently coproduce complex power dynamics and how these are disrupted by participants in various ways. In particular, we reflect on the futility of the "muted researcher" role, whereby attempts at "disembodied neutrality" are met with resistance from participants, with the researcher repeatedly being drawn back into the discussion on the participants' terms.

Preceding our reflexive analysis, we outline some of the literature examining South Africa's culture of protest as well as definitions and understandings of "culture," drawing specifically on the work of Stuart Hall (1997). Following this, we discuss the importance of reflexivity, particularly in focus group research. We then briefly describe the existing body of protest research in South Africa that uses focus group methodology, and we argue for the value of critical reflection in this type of research. Next, we detail the aims of our study and relevant methodological considerations.

\section{Protest in South Africa}

Emerging from peaceful anti-apartheid resistance, which marked the 1950s (e.g., the Defiance Campaign of 1952) and inspired partly by the surge of nationalist resistance throughout Africa in the mid-20th century, South Africa in the 1970s and 1980s saw an upsurge of popular insurrection directed at the oppressive apartheid state, whose reaction to this resistance was frequently violent (Petrus \& Isaacs-Martin 2011; Rauch \& Storey 1998; Sinwell 2011). Perhaps the most infamous incident of state violence during this period was the 1976 Soweto Uprising ${ }^{1}$ which, despite being a peaceful protest, resulted in police officers killing hundreds of school children. At this time, resistance became increasingly radical and militarized, highlighting to a global audience, more than ever before, the plight of "black" South Africans. This heightened global awareness created numerous international solidarities with South Africa's black population (e.g., global sanctions as well as Cuba's involvement

\footnotetext{
${ }^{1}$ The 1976 Soweto Uprising was a response to the Bantu Education Act, which was a piece of apartheid-era legislation that prescribed Afrikaans as the language of instruction in all South African schools. The police fired live ammunition on the peacefully marching students and many were killed (the official figure given by the apartheid government was 23 but it is thought to be closer to 200). Following this, protests - many of which faced violent backlash from the apartheid state — spread across the country (South African History Online, n.d.).

${ }^{2}$ Although we understand racial categories (such as 'black', 'white', 'coloured', and 'Indian') as both socially constructed and discriminatory products of the apartheid system of classification, we use these terms here to reflect the social and structural divisions and inequalities that are a legacy of South Africa's apartheid system.
} 
in the so-called South African Border War), which were pivotal in bringing about the eventual end to the apartheid regime in 1994.

The postapartheid state's embrace of neoliberalism, described by Erasmus (2015, p. 101) as a "dynamic constellation of political projects, power relations, 'structural adjustment' policies and forms of government that provoke struggles about the constitutive making and remaking of necessarily interactive global and local fields of social life," has resulted in only minimal change to the country's economic landscape (Erasmus 2015). Today, South Africa's racial capitalism has facilitated a small black elite joining a white bourgeois class while the majority of the country's mostly black population live in dire financial straits (see Bond 2004; Schneider 2018). Consequently, although the first decade of democracy in South Africa saw a decline in protest (von Holdt 2013a), collective resistance has remained a central facet of the country's civic society (Cornwall, Robins \& Von Lieres 2011; Petrus \& Isaacs-Martin 2011). Today, South African protest action frequently draws from apartheid-era resistance strategy (Runciman 2017). Further, like anti-apartheid resistance, contemporary protest has seen violent clashes between protesters and state actors (see Alexander 2010; Alexander \& Pfaffe 2014; von Holdt 2013a, 2013b). However, today's protest action also differs significantly from that of the past. The protests of South Africa's liberal democracy remain fragmented (community "service delivery" protests are rarely connected with that of the organized working class) and range widely in political orientation (Runciman 2017), at times displaying xenophobic violence. Further, for the first time in almost 400 years, popular resistance in South Africa can be articulated through constitutionally sanctioned democratic channels. However, despite protest action in South Africa now being legal, protests are regulated through various pieces of legislation - such as the Regulation of Gatherings Act 205 of 1993 - which, due to their proximity to the neoliberal state, are subject to bureaucracy and corruption (see Duncan 2016).

The continuities and divergences of popular protest in South Africa were united symbolically in the 2012 Marikana Massacre, ${ }^{3}$ which was the greatest use of force by the state against civilians since the Sharpeville Massacre of $1960 .{ }^{4}$ Marikana, along with numerous other incidents of state-sanctioned violence, has called into question the progress that South Africa has made with respect to justice proper and direct democracy. As Daniel Magaziner and

\footnotetext{
${ }^{3}$ Beginning as a strike for wage increases by Lonmin platinum mineworkers, the Marikana Massacre saw the South African Police Service kill 34 striking miners.

${ }^{4}$ On 21 March 1960, a peaceful crowd of between 5000 and 7000 protestors arrived at a police station. Their intention was to voluntarily give themselves up for arrest for refusing to carry their passbooks, which were issued to black South Africans by the apartheid state as a means of controlling their movement while obtaining their labor in rural and urban areas. In response, the South African Police fired live ammunition into the crowd, killing 69 people and injuring 180 others (South African History Online, n.d.).
} 
Sean Jacobs highlight in a 2012 piece published in The Atlantic, Marikana marks a moment where South Africa's various sociopolitical and economic injustices, although emanating from the country's past and carrying a localized inflection, have merged with the violence inscribed into global capitalist doctrine, including systemic economic inequalities, violations of labor rights, and corporate irresponsibility.

\section{South Africa's culture of protest}

As mentioned earlier, political, academic, and popular discourse frequently infers that South Africa exhibits a culture of protest (see Bruce 2014; Kotze \& Taylor 2010; Montse 2017; Laganparsad 2016; Ndebele 2017; Petrus \& Isaacs-Martin 2011). Petrus and Isaacs-Martin, for example, describe the emergence of a "strike and protest culture" (p. 50). They contend that protests in South Africa are "cultural" in that they are enacted in particular and identifiable ways, inherited from anti-apartheid resistance struggle. The authors mention that this shared history has imbued protest with particular (although, we would add, contested) social meaning in South Africa. The enactment of such protest, they assert, has the tendency to become violent partly because protesters draw on the same repertories of violence that characterized many anti-apartheid protests, such as the burning of tires and blockading roads. They suggest that the recurrent use of these protest symbols are ritualized activities that are particular to protest in South Africa. Similarly, von Holdt and colleagues (2011) assert that the cycle of both police and protester violence may be recreating the apartheid-era "culture of violence" in contemporary South Africa's supposed democratic era. In a later article, von Holdt (2013b) further suggests "violent repertoires have a long life, reproducing themselves within organizational structures and cultures, where they are always available as a resource in future conflict" (p. 118). In the postapartheid liberal democratic system, for example, violent protest action is partly a lasting repertoire from the apartheid era. This violence also represents a response to the structural inequalities and continued marginalization that undergirds the social conditions of a majority of South Africans, most of whom are black (von Holt 2013b).

Although much work has detailed how protesters understand protest in South Africa (e.g., Lodge \& Mottiar 2016; Paret 2015; von Holdt et al. 2011), little has been done to examine the manner by which protesters performatively engage with and contest the representation of this supposed protest culture and the contending histories locked into this. Although antiapartheid resistance is often invoked as informing today's protest culture, we wish to make the critical argument that a contemporary culture of protest in South Africa represents part of a tradition of resistance that spans four centuries. Such a tradition was instrumental in winning what 
freedoms are enjoyed today, and therefore signifies an integral source of identity for many South Africans. The collective nature of protest means that this is as much a collective identity as it is an individual one. Protest culture therefore consists of many contested cultures that are (re)presented in numerous ways, by different actors, and situated in a variety of settings.

The cultural critic Stuart Hall (1997) asserts that cultures are shared meanings and values within which various practices, interpretative frameworks, and dynamics of power operate. Hall maintains that no culture offers an absolute, singular, or pure meaning that can be excavated, with both dominant and marginalized cultures inflecting and drawing from one another in different ways and for different purposes. With respect to a protest culture in South Africa, it is important to note then that such a culture is used differently among, between, and within numerous social groups and individual actors. For example, elite classes do not have an entirely hostile relationship to protest culture as is sometimes believed, with social resistance movements repeatedly being co-opted by elite classes (see Foucault 1980). In South Africa, the ruling political party, the African National Congress (ANC), frequently invokes its position as a former liberation movement as a discursive means of ontological legitimization. Indeed, the party's sloganeering draws on radical activist language (e.g., "radical economic transformation"), despite adhering largely to neoliberal doctrine (see Bond 2004). Likewise, Sinwell (2011) highlights that many protests do not attack elite structures per se; rather, they aspire to be accommodated better within these structures. Various social groups and institutions, all of whom represent a plethora of cultures, embrace and co-opt protest history and culture in different ways.

Hall (1997) goes on to state that we cannot know what culture means outside of how it is represented, and in this regard culture, although harboring material and ideological effects, signifies a struggle for representation and meaning that is largely navigated through language. Animating, and in many ways propelling, this struggle is the differential element of culture, which attempts to extricate "us" from "them" and influences identity formation, power differentials, and notions of normality (see Hall 1997). Thus, the psychological self is always in a dialectical relationship with culture, with each entity informing and (re)forming the other. This means that a culture of protest is, like all culture, far from monolithic and stable. Certainly, the meaning of such a culture remains highly contested and, like protest itself, is subject to continuous shifts in meaning.

With protest representing a performative spatio-discursive disruption of sorts, it follows that the manner by which it connects to culture is, in part, performative. Indeed, protest action is largely made into protest culture through contextually sensitive discourse. In reflexively exploring how protest culture is represented and engaged through discourse by 
participants in the presence of researchers, we may gain insight into how struggles over the representation of South Africa's protest culture operate as well as how the universe of meaning surrounding protest in South Africa is drawn on in the presence of particular audiences.

\section{Researcher reflexivity}

To explore the nuances of how protest culture is represented in the discursive space that is facilitated by the focus group setting, it was vital that the researchers reflect critically on researcher-participant interactional dynamics, which are relatively underexplored in South African protest research. Researcher reflexivity, employed most often in feminist and other critical and/or liberatory traditions, is a means of engaging the power dynamics and structures present in one's immediate setting as well as knowledge-making projects more generally (Burr 1995). Exposing the interconnections between the implementation of the research methodology and the multiple contexts (e.g., personal, historical, political) in which the research takes place is central to critical psychology research processes (Lazard \& McAvoy 2017). Although reflexivity considers the relations between power, knowledge, and self (Daley 2010), it cannot negate the differences and power dynamics intrinsic to all research. Rather, reflexivity embraces these dynamics and strives to minimize their effects. By examining subtle evocations of power and oppression so that we might work toward altering these, reflexivity goes beyond simply highlighting the limits of representation (Malherbe et al. 2017). Instead, it reminds us that researchers do not represent neutral prompts that evoke particular discourses of which they exist outside. Certainly, researchers maintain significant influence over how participants engage the research setting and are, in fact, constitutive of participant discourse, suggesting that analyses must make explicit such influence rather than invisibilize it for the wholly fictive notion of "scientific neutrality."

Reflexivity should not lapse into centralizing the interviewer at the expense of the participant, nor should it be reduced to hollow lists of the researchers' identity markers (e.g., race, class, gender, sexuality, etc.) in an attempt to acknowledge power differentials. Reflexivity should also not be enacted in a manner that resembles experimental research's preoccupation with "listing" extraneous variables. Instead, we must extend personal reflexivity to include epistemological reflexivity so that we may contextualize personal reflections and elucidate how the researcher's theoretical and methodological assumptions influence the production of knowledge (Lazard \& McAvoy 2017).

Researchers must undertake the difficult and ongoing process of interrogating our complicity in the perpetuation, maintenance, and reproduction of numerous unequal dynamics of power and the violence therein (Pillow 2003). As such, researchers should acknowledge their intersecting identity categories, their 
institutional affiliations (i.e., their position within the academy and any other organizations that hold, prohibit, and/or produce power; Pillow 2003), and their epistemological stance towards their research (Lazard \& McAvoy 2017). However, power is not static; it is, as Foucault's work (1980) reminds us, everywhere. People's constantly shifting subject positions can dislocate power within the research setting, thereby creating new and potentially liberatory knowledges of resistance that visibilize the fluidity and contextually sensitive nature of all knowledge forms (Daley 2010). Researchers must consider how such resistance can be harnessed toward instituting more egalitarian research practices.

\section{Interrogating researcher-participant interactions in focus groups}

Although reflexivity has been considered in focus group research, it is relatively uncommon for those involved in such research to commit to indepth critical reflections of the research process, such which engages directly with the power differentials and other interactional dynamics that exist within focus groups (Getrich et al. 2016). Focus group methodology may be understood, broadly, as conversations that take place between participants. These conversations center on a particular topic, which is generally selected by researchers, who typically facilitate the discussion through a series of questions and/or prompts (Wilkinson 1998a).

Those researchers who have published critical reflections on focus group research provide valuable insight into the complex discursive dynamics that unfold throughout the focus group process (e.g., Getrich et al. 2016; Grønkjær et al. 2011; Hydén \& Bülow 2003; Underwood, Satterthwait \& Bartlett 2010). For example, they reflect on the methodological issues and theoretical dilemmas encountered when conducting focus groups with participants from vulnerable populations, such as children (Morgan et al. 2002), people with disabilities (Gates \& Waight 2007; Woodring et al. 2006), and people struggling with mental health (Owen 2001).

In addition to the dilemmas related to conducting research with participants from particular groups, these researchers have also considered specific issues emerging in focus group interactions more generally. Such reflections have examined various kinds of dynamics, including how local context (i.e., specific issues and events) and macro-geographies (i.e., global, transnational, national) influence focus group discussions (Hopkins 2007); how homogeneity in focus group construction affects interaction and content (Grønkjær et al. 2011); and how focus group discussions should be analyzed as situated talk to account for the different ways that participants constitute themselves and others throughout the discussion, and shift between these various interactional modes (Hydén \& Bülow 2003). 
Focus groups are "messy." They constitute a complex series of processes within which, unlike individual interviews, participants are able to collaboratively institute strategic silences and discursive detours that resist the intended focus of the discussion (Wilkinson 1998b). Accordingly, some researchers have considered the functionality of silence in focus groups. For example, Pösö, Honkatukia and Nyqvist (2008), in examining the use of focus groups to study meanings of violence with youth in reform schools, reflected on focus group participants' silence on certain issues around violence that had been prominent in previous discussions. They also reflected on how their behavior as researchers may have inadvertently silenced certain views during the discussions. In another instance, Getrich et al. (2016) used a critical incident lens to explore the context and interactional dynamics of focus groups, wherein they reflected on the tension between choosing to silence participants who espoused inaccurate and potentially damaging information and not wanting to offend participants.

Paying attention to these unplanned "critical incidents" in focus group research serves to enrich analyses and contribute to wider debate on the practicalities of focus group research (Getrich et al. 2016). Puchta and Potter (1999) highlight that in focus group discussions, researchers face a conflict between attempting to institute a nonthreatening environment in which there are no "wrong answers" and employing a detailed interview schedule that requires answers (rather than silence) from participants. In responding to the kinds of tensions and "messiness" that characterize focus groups, reflexivity allows researchers methodological flexibility and a procedural adaptability of sorts (Underwood, Satterthwait \& Bartlett 2010). It may then be argued that if researchers reflexively analyze focus group process in a transparent and honest manner, with a particular emphasis on the unexpected, unintended, and "problematic" moments within such research, we may begin to de-alienate the research while engaging deeply with its social utility (Underwood et al. 2010).

Despite the clear benefits of reflexivity in focus group research, as outlined above, in the considerable corpus of South African protest literature that uses focus groups as a means of data collection, little research offers a reflexive analysis of the researcher(s) or employs a reflexive standpoint (see Dawson \& Sinwell 2012 for a notable exception). In South African protest research, focus groups have been used to examine participants' understandings of the purpose of protest (Lodge \& Mottiar 2016), the meanings participants attach to "violent protest" (Paret 2015), the lived experiences of community activists in relation to the right to protest (Duncan 2016), the similarities and differences between the use of protest by the poor and working class (Alexander \& Pfaffe 2014), the degree to which the perception of a lack of participation in public spaces promotes protest (Mchunu \& Theron 2013), the forms of "nano-media" (i.e., 
demonstrations, songs, slogans, dress, dance) used by community-based movements in claim-making and mobilization (Dawson 2012), the use of mobile phones in social justice movements (Chiumbu 2012), the discursive practices of social movements in South Africa (Chiumbu 2015), and protesters' subjective embodiments through hegemonic masculinities (Langa \& Kiguwa 2013). Although this is clearly a well-developed research field, the position of the researcher and the participant-researcher interaction in South African protest research has been underconsidered.

It is perhaps notable that critical reflexivity is not a traditional requirement of the academy beyond, in some cases, a brief or passing acknowledgment (Malherbe et al. 2017). For critical psychological research, reflexivity should not be relegated to a peripheral concern; rather, as Lazard and McAvoy (2017) assert, it should be "integral to generating insights about topics and the questions we choose to ask about them and as such becomes central to the exercise of building knowledge" (p. 15). Therefore, in drawing explicitly on a praxis of reflexivity within our analysis, we seek to highlight how "reflection in action" (Daley 2010 p. 80) is able to frame analyses and interpretations of South Africa's culture of protest.

\section{Aims}

In this article we focus on how protesters discursively contest, (re)produce, and negotiate protest culture in the presence of researchers (i.e., cultural Others) - whose identities are discussed in more detail below - and their comrades. In so doing, we seek to advance two central objectives: to provide a contextual examination into the manner by which protest culture in South Africa is discursively constituted and to what ends such constructions function; and to recognize the effects that the researcher as well as the broader research context has on focus group discussions in protest research. We seek to draw out how protesters engage an apparent culture of protest to and for researchers, whose identities are largely representative of the bourgeois class interests against which much protest in South Africa is and has been directed.

\section{Method, sample and setting}

This study was undertaken in a low-income informal settlement on the periurban outskirts in the southwest region of Johannesburg, South Africa. This particular community is densely populated and consists of approximately 8 000 households (SERI, 2014). The community presents a noted history of public protest, some of which is characterized by violence, with many clashes among protesters, other community members, and the police. The 
community's formal interactions with authorities on issues such as service provision and relocation have been largely unsuccessful.

The study is located within a broader project examining the experiences of protest of residents living in this community. For the purposes of this particular article, as we were conducting an in-depth critical reflection, we chose to focus on one particular focus group discussion which took place with discussants who were recruited through key informants in the community. Within this specific focus group, three men and three women between ages 25 and 55, who demonstrated variations in formal and informal education levels as well as low levels of formal employment, served as participants. With their permission, the focus group discussion was audio-recorded and transcribed verbatim. Although the discussion was conducted primarily in English, participants also spoke Sotho and $\mathrm{Zulu}^{5}$ in the focus group. This was later translated into English and then back-translated into the original languages as a means of validating the original translations.

\section{Analysis: reflexively employing discursive psychology}

Discourses may be understood as the different ways of referring to or constructing particular knowledges. They represent a cluster of ideas, images, and practices that provide ways of talking about positioned knowledge forms. Discourses define what (as well as who) is appropriate, useful, relevant, and "true" within specific contexts and therefore are concerned with both the politics and the effects of different meanings (Hall 1997). The method of discourse analysis proposed by Potter and Wetherell (1987), usually referred to as discursive psychology, uses discursive techniques to analyze talk and applies these analyses to real world settings (Potter \& Hepburn 2007).

Discursive psychology is concerned primarily with identifying interpretive repertoires, which are broadly discernible linguistic devices, used with some stylistic coherence, on which people draw when discursively constructing actions and events. They are usually organized around a particular metaphor or trope and encompass grammatical regularity. In this respect, interpretive repertoires enable order to emerge from the seemingly chaotic and arbitrary form of everyday language. Repertoires are flexibly drawn upon to perform a number of functions which, consequently, result in much variability or contradiction within discourse. It follows then that interpretive repertoires are used in accordance with their suitability to one's immediate context (Potter \& Hepburn 2007; Potter \& Wetherell 1987). This variability is the rule rather than the exception and signifies that, by drawing on a number of discourses, language aims to achieve different things at different points in a text. Similarly, it is important to make note of a discourse's flexibility, where the same kind of account is used to

${ }^{5}$ Two of South Africa's 11 official languages. 
perform different social actions. However, identifying interpretive repertoires is not enough; researchers must recognize the use and function of power between and within repertoires as well as the problems generated by their existence (Burr 1995; McKinlay \& McVittie 2008).

The notion of critical reflexivity (as outlined above) that informs our use of discursive psychology will be considered against the manner by which data were produced (ontologically, politically, epistemically, and institutionally) within the research context, as well as how we as researchers have interpreted these data. Following this, the first author Josephine Cornell (i.e., the author who facilitated this particular focus group) identifies as a white, middle-class woman living in the Western Cape. The other authors, who were not present in this focus group discussion but were involved in the conceptualization of the project and the analysis and writeup of the data, identify respectively as a white middle-class man (Nick Malherbe), a black middle-class woman of Indian descent (Shahnaaz Suffla), and a black middle-class man of Indian descent (Mohamed Seedat). Epistemologically, all four us are orientated toward critical community psychology, social constructionism, and critical social theory. Two other colleagues, Sizakele Buthelezi and Royal Lekoba, were also present in the focus group discussion but did not actively participate. Royal, who is not a research team member but is responsible for community engagement and liaison and identifies as a black man, assisted with translation when necessary. Sizakele, who identifies as a black woman, was also not a research team member for this particular project. However, she provided additional translation assistance when it became apparent that the focus group discussion was going to proceed in multiple languages.

All six participants in this study identify as working-class and as black. They live and frequently protest in a low-income community located in Johannesburg, the capital city of the Gauteng province, which at the time of this study was governed by the country's ruling political party, the ANC.

\section{Findings and discussion}

In exploring how participants constituted protest culture and how researchers/facilitators and the research context influenced the focus group discussion, we encountered issues of ownership, power, discursive signification, resistance, silence, and (in)visibilization. In this section, our analytical narrative is organized into four sections, each attempting to build on and speak to one another in different ways. Drawing on this analysis, we then consider how facilitators might engage the focus group space in a manner that is both transparent and sensitive to power differentials, illusions of neutrality, and subjective positionalities. 


\section{Rewriting the research space through silences}

The initial intention of the focus group was to discuss the meanings that participants discursively attached to a protest (which we had understood to be peaceful) that occurred in their community, as well as the meanings associated with a more general notion of peaceful protest. Following formal personal introductions between participants and our group, the facilitator (Josephine) invoked the protest in question and introduced the focus group thusly:

Josephine: And was anyone at the [peaceful] protest? [5 second silence] Do you remember it at all? [4 second silence] Okay, can anyone remember a peaceful protest that happened at the end of last year? We'll go around and maybe if you can tell me a bit about why you think that protest was peaceful and maybe describe it a bit. (Extract 1)

Despite focus group facilitators frequently making their particular "stake and interest" explicit in the way that they open up focus groups, the manner by which introductions influence the trajectory of the discussion is a largely underexplored facet of discursive psychology as well as other kinds of qualitative research (Potter \& Hepburn 2005, p. 296). In Extract 1, although we had designed an interview schedule that sought to probe participants' discursive constructions of peaceful protest, participants seemed to use silence as a tool with which to exert their discursive ownership over the research space, thereby withdrawing from the conversation and refusing our terms of engagement (Wilkinson 1998b). Eventually breaking the silence, P2 interjected (in Extract 2 below) that with peaceful protests "the government won't listen to us," thereby constructing peaceful protest as futile and perhaps even oxymoronic. He then appeared to redirect the focus of the discussion to South Africa's culture of violent protest and thus, in our reading, not only delineated how the conversational space was to be remade, but also actively reshaped the discursive coordinates along which discussants were to adhere when approaching such a culture within this research space.

\section{Signifying culture and tradition}

P2: [laughs] Okay (...) a protest is not supposed to be violent, we're supposed to voice yourself, but the problem is the culture that we do have as South African people from way back, protests are not supposed to be friendly. We are not heard if we are friendly. If we want to go about singing Kumbaya on the street the government won't listen to us, but at the end of the day if we become violent and attract his attention (...) you're trying to address him. So, yeah, peaceful marches, they are needed but we need to change - what you call this? - psychological aspects of our kids because as long as [refers to P1 by name] is still alive from that generation of 1976, guess what? There's no peaceful protest. Me in 1976 I was still young, and try to implement a peaceful protest to our kids, it will happen but let the government be there to answer our questions because (...) you write 
him a letter he doesn't answer, he's neglective [sic]. So, that's why people are violent, so the government can take note of us. (Extract 2)

As Pösö et al. (2008) highlight, focus groups are valuable for capturing meanings and definitions of violence which otherwise might not be voiced as explicitly in individual interviews. In Extract 2, P2's interpretive repertoire seemed to attempt to legitimize violent protests by constructing them in relation to their utility. Established by this discursive repertoire is a murkily conceptualized notion of violence as that which marks a protest's functionality. Perhaps, though, it is not violence per se which characterizes a protest's utility, but rather that violence is able to garner attention within contemporary South Africa's liberal democracy, wherein voice and legitimate channels of communication are available most readily to the, majority white, middle classes, who embody hegemonic politics of respectability (von Holdt 2013a). The interpretive repertoire on which P2 draws appears to consider how traditions of violent protest inform the country's protest culture. As Williams (1977) reminds us, tradition is always a selected version of the past that attempts to ratify the present to guide the future. Bhabha (1994) similarly asserts that rather than a faithful sign of historical memory, tradition represents a form of authority in terms of the archaic. Accordingly, in stating "the culture that we do have as South African people from way back, protests are not supposed to be friendly," P2's repertoire seems to explicitly link the violence that marks contemporary protest culture to traditions of anti-apartheid resistance. In this way, tradition is both "made" and "used" for particular rhetorical purposes, that is, a loosely defined form of violence is constructed as working within a revered anti-apartheid tradition (see Bond 2004).

Although repeatedly evoking " 1976 " viscerally and symbolically signifies violence in the context of protest, the interpretive repertoire does not acknowledge that the Soweto Uprising was initially conceived of as a peaceful protest. This protest event (wherein violence was used by the state rather than by the protesters) is, in our understanding, paradoxically, used to signify a laudable tradition of violence within protest. Alternatively, references to 1976 may be read as alluding to the presence of state violence irrespective of whether a protest is violent. Regardless, the repertoires seem to indicate that protest culture is passed on through the tradition of violent protest. We do not intend to imply here that violence does not exhibit a tradition within protest in South Africa (see James 2012 for an account of violence and revolt in preapartheid eras), or indeed that we are in a position to moralize violence by deciding where, when, for whom, and for which purposes it is appropriate. Rather, we wish to emphasize that with regards to protest in South Africa and the "cultures" constructed in relation to this, 
the past is drawn on selectively as a means of constructing particular traditions and, consequently, particular representations and significations of culture. In fully examining representations of protest culture and associated traditions, we must take into account the addressees for whom such representations are constructed and signified, which in the present study constituted participants' comrades and our group.

\section{Observing currents of power within discursive performance}

The interpretive repertoires drawn on by P2 (in Extract 2) and P1 (in Extract 3) continue to legitimize the use of violence in protests, albeit to the subjection of discursive slippage. Where P1's interpretive repertoire appears to foreground nationality in South Africa's culture of protest by noting that "the culture that we... have as South African people from way back," the interpretive repertoire drawn on by P2, seems to locate race as the fulcrum of such culture. Although we do not perceive these repertoires as denying the dialectical entanglement of race, nationality, and culture, it seems that, for different rhetorical purposes, it is either race or nationality that emerges as the salient mark of protest culture.

P1: If ever we make a peaceful protest, they [the authorities] don't understand (...) Let me make an example now. We made so many protests, and we fight for electricity, and housing and the place, it don't belong to us (...) But we fight, now it's 37 years (Josephine: That's a long time). Immediately when Unisa [name of our institution] came to us, they said, "Please, don't fight. We as Unisa will try to make the electricity here in [name of community]." Immediately when they [the authorities] hear that, they go to fix the electricity. Now there is electricity. Not to say it's because of our fight, they don't care about us. But because of you, they have already done that electricity, they are busy with it even now. So, to fight, it's better (...) because it's our culture, and no one can change my skin to white. I'm not white, I can't be white. (Josephine: So, you think it's a cultural thing?) It's a culture of a black person! (Extract 3)

Discursively linking culture to race (and, in some instances, making one synonymous with the other) usually produces specific effects with respect to power in the research setting. The first of such effects typically sees an explicit differentiation between participants and facilitators. As Eagle (2005) notes, tying culture to a single definition results in the development of a politics of representation around the purposes (sometimes oppressive) for which culture is discursively used. Constituting race as culture, or indeed culture as race, within discourse has a particular history in South Africa, whereby each construct has been used to essentialize and interiorize the black Other to sustain the ideological dominance of "whiteness". In Extract 3, culture appears to be made synonymous with the experience of blackness, placing the white facilitator outside of this position and the speaker, through his access to particular experiences, in a position of discursive, and relatedly 
ontological, authority in this space. In reference to Hall's (1997) insistence that any attempt to fix meaning signifies power intervening in discourse, P1's interpretive repertoire seems to displace the researcher-as-expert within the research setting. In this way, an inversion of the assumed power relations takes place, while hegemonic racist discourses around a monolithic black culture are reappropriated.

A discursive maneuver of the sort instituted in Extract 3 reminds us that reflexivity is not merely a means by which researchers and focus group facilitators must understand power in a limited and patronizing sense, that is, a conceptualization of power as that which is possessed by the researcher/ facilitator exclusively. Rather, in following from Foucault's (1980) work, power is everywhere (albeit concentrated more in some places than others). Reflexivity, therefore, requires that we remain sensitive to the various ebbs and flows of power, how participants exercise power within the research space, and what this means for how data are constituted and collected. In focus group discussions, for example, participants hold the potential to rearrange constitutions of power between facilitators and themselves by resisting the focus group agenda and seizing control of the conversational focus (Wilkinson 1998b). Although research unfolds within discursive parameters that are ultimately set by researchers/facilitators, these can, and usually do, result in participants' own discursive resistance, subversion, and negation.

Broader systems of power, many of which relate to structural violence (see Galtung 1969) in which all attempts at discursive power inversion and/or resistance are embedded, in this focus group discussion were highlighted when P1 noted in Extract 3 that the institution to which we are affiliated holds the kind of power necessary to negotiate with government the supply of electricity to this informal settlement. Although such a negotiation is difficult, when institutional affiliations are made visible (a source of power which, although structuring the entire research process, is typically muted in research data) we are reminded that beyond such moments of resistance and discursive remaking, the institutional affiliations and cultures that inform research remain largely antithetical to the oppressive social circumstances which mark the lives and inform the protests and protest cultures of participants.

\section{Visibilizing facilitator footing positions}

In all focus group discussions, the footing of the facilitator is variable and slippery. The facilitator can be constructed by participants as simultaneously representing personal and institutional footing positions (see Potter \& Hepburn, 2005). In this research space, although the facilitator is 'white', the two other colleagues present in the focus group discussion identify as 'black'. Nonetheless, participants' interpretive repertoires appeared to 
position our institution as approximating a culture of 'whiteness'. In this focus group, the facilitator leading the focus group discussion seemed to be positioned by participants as a cultural outsider, both as a facilitator from a particular institution that holds power and influence and as a white middleclass woman. This is noted in Extracts 4 and 5, where the facilitator (rather than the institution that she represents) is challenged on her silence and the apparently neutral nonstance facilitators are expected to embody in research settings. In this way, the facilitator, from the footing positions of a gendered and raced body, as well as an ideological representative, was brought explicitly into the focus group discussion.

P2: Will you agree if I say it's culture? [laughter] [addressing Josephine]

P3: If you don't know to say it's a culture, where [did] you grow up? You [addressing Josephine].

Josephine: Me? Where did I grow up?

P3: If you don't know to say this is a culture of South Africa!

Josephine: I'm interested to hear what you say

Sizakele: Our opinion doesn't count

Josephine: Our opinion doesn't count

P2: But it should! But it should! How it doesn't count? (Extract 4)

Extract 4 seems to demonstrate the manner by which participants instated a complex discursive resistance to the facilitator's (muted) attempts to remain politically "neutral" throughout the focus group discussion. Although it is unlikely all participants subscribe to a common definition of protest culture (and, in this sense, it is probably more accurate to speak of protest cultures), in our reading, the interpretive repertoires drawn on by P2 and P3 in Extract 4 demonstrate a kind of discursive solidarity that resists the facilitator's nonposition. In response to the facilitator's attempted positional silence, P2's repertoire seems to imply that the facilitator displays an ignorance toward the culture of violence that informs protest (and protest culture) in South Africa, thereby negating her status as a real South African. Simultaneously, the facilitator's refusal to engage this conversation appears to signal for participants her inability to embody a legitimate political stance. The potential of harnessing a shared national identity, in the context of so many other differing identities, seems to be denied to the facilitator because of her inability/refusal to engage meaningfully with participants and the discussion that they had instituted.

Where facilitator silence, that is, the deliberate withholding of voice, was intended to establish a space within which the concerns of 
participants were centralized, it had the converse effect of bringing the facilitator to the center of the discussion. Indeed, the facilitator's silence appeared to be interpreted as her being unconvinced of the culture of protest advocated by the speakers, thereby establishing further distance between the facilitator and the participants. In our understanding, it was in response to this that participants took up various discursive tools to "convince" the facilitator of the legitimacy of their position. In response to the facilitator's positional muting, one participant asks in Extract 4, "If you don't know to say it's [protest] a culture, where [did] you grow up?", thus appearing to excavate the facilitator's political position from her socio-geographic position while creating and authorizing a discursive space within which she was able to enter the discussion. Later in the focus group, a participant was made aware that the facilitator lived in the Western Cape and not Gauteng (the South African province wherein this community is located), to which he responded:

P2: What's a birthday party without a birthday cake? If you are going to protest then it's tires behind. You go join your Verwoerd and people behind and do your peaceful marches. They'll listen to you because you are that side [the Western Cape], hey, Helen Zille did it in style, she protested, like, you don't wear your heels in a protest! You have to be in your takkies [running shoes]. (Extract 5)

Here, it appears the legitimacy, supposed neutrality, and intentions of the facilitator are discursively challenged by the participant, who seems to use the possessive personal pronoun "your" to link the facilitator's "whiteness" to a familiarity to and an ownership of the legacy of Hendrik Verwoerd, the former prime minister of South Africa, commonly referred to as "the architect of apartheid." In this way, the discursive vacuum instituted by the facilitator's silence appears to be used by participants to attribute to her - and perhaps remind her of her status as a beneficiary of - legacies of South Africa's oppressive history, against which much protest emerges as oppositional. Peaceful marches then become representative of the facilitator as a white, middle-class, female body from the Western Cape. Later, in Extract 5, P1 goes on to say, "They'll listen to you because you are that side [the Western Cape]." "That side" is significant here; at the time of this study, the Western Cape was governed by the Democratic Alliance (DA), a center-right political party formed in 2000 as a merger between the National Party (NP) and the Democratic Party (DP). There are clear racialized and racist connotations associated with the DA: the NP was the governing party under apartheid and the DP became the official opposition to the ANC in the 1994 elections through pitching an electoral campaign (to 'white', 'Indian', and 'coloured' voters) that was said to be against crime, corruption, and, implicitly, a black (African) dominant political system (Saul 2014). Today, the DA remains a political party characterized by policies that cater to South Africa's middle 
classes. References to Helen Zille, the controversial white premier of the Western Cape and former leader of the DA, as enacting a kind of bourgeois, illegitimate protest in "heels" attempts to link apartheid legacies directly to present-day governance in the Western Cape. Discursively highlighting that the white, silent facilitator (and what could be thought of as her white silence) is from the Western Cape seems to further situate her as an outsider, both experientially and politically, thereby rendering illegitimate her voice as well as her subjectivity in discussions and understandings of South Africa's protest culture. Echoing Hopkins (2007), this interaction between P2 and the facilitator also underscores the importance of considering the local, national, and global geopolitical events and contexts in which a focus group is situated. The macro-geographies, such as the fact that the focus group took place in Gauteng whereas the facilitator was from the DA-run Western Cape, as well as the broader history of apartheid and protest in South Africa, influenced the interactions in the focus group and are as analytically valuable as the finer points of discussion within the focus group (Hopkins 2007).

In the facilitator's attempt not to interfere with the data by overinvolving herself in the focus group discussion, she inadvertently assumed the positivist position of the all-knowing, disembodied facilitator, which the critical community psychology orientation of our research seeks to challenge. Although reflexivity requires researchers and facilitators to acknowledge their position and their presence in research settings, reflexive analytical attention is rarely afforded to silence, or indeed attempts to mute facilitator presence by continually shifting discursive attention onto participants. There is an implicit, perhaps patronizing, assumption undergirding practice of this sort, whereby the researcher and/or facilitator is considered to occupy a position of such epistemic value and power that bringing the self into the interview context in any way would influence too much participants' thinking, thereby contaminating the data. Yet as the repertoires drawn on by the participants make clear, silence carries an equally significant discursive influence that disregards the agency of participants. Certainly, to approach a research space that is, as far as possible, co-constituted by facilitators and participants, we as facilitators need not proceed from the false, or contradictory, assumption that the research setting is "theirs" only through "our" silence.

\section{Conclusion}

Although numerous scholars working in the feminist, critical psychological, and liberatory traditions have explored, reflexively, the manner by which researcher and facilitator presence shapes and informs data and the data collection process (e.g., Daley 2010; Lazard \& McAvoy 2017; Malherbe et al. 2017); how researchers/facilitators inadvertently silence certain viewpoints in focus group discussions (e.g., Pösö et al. 2008); and how participants 
collaboratively institute silences on certain topics (e.g., Wilkinson 1998b), there has been little reflexive analytical consideration of how "muted facilitators" influence focus group discussions. Therefore, participants' discursive modes of resistance to the uneven power arrangements that characterize the research setting, as well as the facilitator's silence, represents a valuable albeit understudied facet of reflexive engagement within critical community psychology work.

In the present study, what we had intended to be a discussion about peaceful protest was discursively reconstituted by participants as a conversation on protest culture, the place of violence therein, as well as issues of authority, ownership, and legitimacy of this culture. We had attempted to host a discussion on participants' perspectives on a particular protest that we had deemed peaceful and which had occurred in this community. This agenda was immediately rejected by participants, who demanded the facilitator's discursive participation. In exploring participants' discursive resistance, the present article responds to Getrich et al.'s (2016) call for researchers/facilitators (particularly those working in community settings) to reflect on what happens during the messiness of the focus group process and to examine how, and perhaps why, focus group discussions frequently veer from an idealized research agenda. Accordingly, the article examines how a middle class white female facilitator's self-silencing influenced her facilitation of a focus group discussion with poor black discussants, who undertook a discursive remaking of sorts that, ironically, acted to centralize the facilitator in their discussion on protest culture.

We may then consider protesters - and protest more generally - as embedded within numerous resistance cultures that remain dialectically entangled with ever-shifting meanings, values, and principles, all of which are fundamental to the formation of identity. Culture cannot, however, be conceived of as an extraneous variable whose study requires its contextual isolation. Instead, critical researchers and facilitators must engage the situatedness of cultural representations, including the bodied presence of researchers/ facilitators and the cultures we represent, which, although in some respects align with grassroots struggle, also signify the bourgeois class interests toward which such struggle is directed. We therefore call for researchers and facilitators to consider protest as well as protester solidarity as embedded within a number of cultures which, despite their inherent representational politics, may be drawn on as a unified entity for various rhetorical reasons.

Researchers and facilitators who are situated in a critical paradigm, as we consider ourselves to be, tend to enact reflexivity in a somewhat contradictory fashion, whereby attempts to acknowledge our role in influencing the data result in an attempt to distance ourselves as much as possible from the focus group discussion. In this study, participants repeatedly drew in the facilitator, who, not wishing to influence the data too heavily, reverted discussion back to how participants understood protest culture. However, differences between the 
facilitator and participants (specifically, raced renderings of class) became aggrandized through her silence. These differences were then drawn on in participants' interpretive repertoires to unauthorize the facilitator's positionality within discussions around protest by excluding her, and her assumed endorsement of peaceful protest, from the tradition and culture of liberatory resistance movements in South Africa. Within the discursive vacuum that was instituted through the facilitator's self-silencing, participants could remake her positionality to suit their own rhetorical ends, which saw a particular construction of protest culture.

Following from this, we suggest that researcher/facilitator silence holds the potential to delegitimize researchers/facilitators; patronize participants by assuming their diminished subjecthood and lack of agency in research settings; and is open to mistranslation or, rather, an open hermeneutic to be used by participants for their own rhetorical purposes. Although there are clear power differentials in research spaces that cannot be denied or erased, it is apparent in this context that researchers and facilitators should not attempt to mute the self in any way. In facilitating participant voice, it does not follow that the researcher/facilitator should subscribe to a fictive position of "nonvoice." Openly entering discussions beyond mere facilitative prompts may, in a manner that is sensitive and is endorsed by participants, encourage rapport, trust, and a working relationship, even in cases where participants' views do not cohere with that of the researchers/ facilitators. As Bhabha (1994) notes, destabilizing theory/action binaries that segregate the researcher from the researched activist do not require a unity to be produced between antagonisms and contradictions. Rather, the task is to speak to such tensions openly and directly. In so doing, we may enable an open and honest discussion where the articulation of power is announced instead of disallowed through silencing and the presumption of its location and its limits.

\section{Acknowledgements}

We would like to thank Royal Lekoba and Sizakele Buthelezi for their assitance with translation.

\section{Funding}

The author(s) disclosed receipt of the following financial support for the research, authorship, and/or publication of this article: This project is supported by the South African Medical Research Council Intramural Research Fund [grant number 47541]; and Unisa Ukuphepha 2: Demonstrating Compassionate and Safe Communities in Africa [project code 822500].

\section{ORCID}

Josephine Cornell (D) http://orcid.org/0000-0002-0933-9030

Nick Malherbe (i) http://orcid.org/0000-0002-4968-4058

Shahnaaz Suffla (i) http://orcid.org/0000-0002-4597-5472

Mohamed Seedat (D) http://orcid.org/0000-0001-9018-3370 


\section{References}

Alexander, P 2010, 'Rebellion of the poor: South Africa's service delivery protests - a preliminary analysis', Review of African Political Economy, vol. 37, no. 123, pp. 25-40.

Alexander, P \& Pfaffe, P 2014, 'Social relationships to the means and ends of protest in South Africa's ongoing rebellion of the poor: the Balfour insurrections', Social Movement Studies, vol. 13, no. 2, pp. 204-21.

Bhabha, HK 1994, The location of culture, Routledge, Oxford.

Bond, P 2004, Talk left, walk right: South Africa's frustrated global reforms, University of KwaZulu-Natal Press, Pietermaritzburg.

Bruce, D 2014, 'Violent protests entrenched in SA's culture', The Mail and Guardian, 13 Feb. 2014, https://mg.co.za/article/2014-02-13-violent-protests-entrenched-in-sas-culture, Viewed date: 16 March 2018.

Burr, V 1995, An introduction to social constructionism, Routledge, London.

Chiumbu, S 2012, 'Exploring mobile phone practices in social movements in South Africa: the Western Cape anti-eviction campaign', African Identities, vol. 10, no. 2, pp. 193-206.

Chiumbu, S 2015, 'Social movements, media practices and radical democracy in South Africa', French Journal for Media Research, vol. 4, pp. 1-20.

Cornwall, A, Robins, S \& Von Lieres, B 2011, 'States of citizenship: contexts and cultures of public engagement and citizen action', IDS Working Papers, vol. 2011, no. 363, pp. 1-32.

Daley, A 2010, 'Reflections on reflexivity and critical reflection as critical research practices', Affilia, vol. 25, no. 1, pp. 68-82.

Dawson, MC 2012, 'Protest, performance and politics: the use of "nano-media" in social movement activism in South Africa', Research in Drama Education: The Journal of Applied Theatre and Performance, vol. 17, no. 3, pp. 321-45.

Dawson, MC \& Sinwell, L 2012, 'Ethical and political challenges of participatory action research in the academy: reflections on social movements and knowledge production in South Africa', Social Movement Studies, vol. 11, no. 2, pp. 177-91.

Duncan, J 2016, Protest nation: the right to protest in South Africa, University of Kwazulu Natal Press, Pietermaritzburg.

Eagle, G 2005, “Cultured clinicians": the rhetoric of culture in clinical psychology training', Psychology in Society, vol. 32, pp. 41-64.

Erasmus, Z 2015, 'The nation, its populations and their re-calibration: South African affirmative action in a neoliberal age', Cultural Dynamics, vol. 27, no. 1, pp. 99-115.

Foucault, M 1980, Power/knowledge: selected interviews and other writings, 1972-1977, Pantheon, New York.

Galtung, J 1969, 'Violence, peace, and peace research', Journal of Peace Research, vol. 6, no. 3, pp. 167-91.

Gates, B \& Waight, M, 2007, 'Reflections on conducting focus groups with people with learning disabilities: theoretical and practical issues', Journal of Research in Nursing, vol. 12, no. 2, pp. 111-26.

Getrich, CM, Bennett, AM, Sussman, AL, Solares, AL \& Helitzer, DL 2016, 'Viewing focus groups through a critical incident lens', Qualitative Health Research, no. 26, vol. 6, pp. 750-62.

Grønkjær, M, Curtis, T, de Crespigny, C \& Delmar, C 2011, 'Analysing group interaction in focus group research: impact on content and the role of the moderator', Qualitative Studies, vol. 2, no. 1, pp. 16-30.

Hall, S 1997, 'Introduction', in S Hall (ed.), Representation: cultural representations and signifying practices, Sage, London, pp. 1-11.

Hopkins, PE 2007, 'Thinking critically and creatively about focus groups', Area, vol. 39, no. 4, pp. 528-35. 
Hydén, LC \& Bülow, PH 2003, 'Who's talking: drawing conclusions from focus groupssome methodological considerations', International Journal of Social Research Methodology, vol. 6, no. 4, pp. 305-21.

James, CLR 2012, A history of pan-African revolt, PM Press, Oakland.

Kotze, JS \& Taylor, D 2010, 'Ke nako: service delivery as a key challenge for the Zuma administration - a developmental local government perspective', Africa Insight, vol. 40, pp. 198-212.

Laganparsad, M 2016, 'Tribalism mixed in protest culture', The Sunday Times, 8 May 2016, https:// www.timeslive.co.za/sunday-times/news/2016-05-08-tribalism-mixed-in-protest-culture/, Viewed date: viewed: 20 March 2018.

Langa, M \& Kiguwa, P 2013, 'Violent masculinities and service delivery protests in post-apartheid South Africa: a case study of two communities in Mpumalanga', Agenda, vol. 27, no. 1, pp. 20-31.

Lazard, L \& McAvoy, J 2017, 'Doing reflexivity in psychological research: what's the point? What's the practice?', Qualitative Research in Psychology, doi:10.1080/14780887.2017.1400144.

Lodge, T \& Mottiar, S 2016, 'Protest in South Africa: motives and meanings', Democratization, vol. 23 , no. 5, pp. 819-37.

Magaziner, D \& Jacobs, S 2012, 'The end of South African exceptionalism', The Atlantic, 27 Aug. 2012, https://www.theatlantic.com/international/archive/2012/08/the-end-of-southafrican-exceptionalism/261591/,Viewed date: 15 March 2018

Malherbe, N, Suffla, S, Seedat, M \& Bawa, U 2017, 'Photovoice as liberatory enactment: the case of youth as epistemic agents', in M Seedat, S Suffla \& DJ Christie (eds.), Emancipatory and participatory methodologies in peace, critical, and community psychology, Springer International Publishing, Cham, pp. 165-78.

Mchunu, N \& Theron, F 2013, 'Contextualising public protest: the case of Khayelitsha', Administratio Publica, vol. 21, pp. 105-28.

McKinlay, A \& McVittie, C 2008, Social psychology and discourse, John Wiley and Sons, London. Montse, T 2017, 'Opinion: protests are a cry for help from the have-nots', Sowetan Live, 29 Jan. 2017, https://www.sowetanlive.co.za/news/2017-01-29-opinion-protests-are-a-cry-forhelp-from-the-have-nots/, Viewed date: 10 March 2018

Morgan, M, Gibbs, S, Maxwell, K \& Britten, N 2002, 'Hearing children's voices: methodological issues in conducting focus groups with children aged 7-11 years', Qualitative Research, vol. 2, no. 1, pp. 5-20.

Ndebele, N 2017, 'We need a second revolution to regain our freedom', Daily Maverick, 18 Nov. 2017, https://www.dailymaverick.co.za/opinionista/2017-11-18-we-need-a-secondrevolution-to-regain-our-freedom/\#.WpPDX66WbIV, Viewed date: 08 March 2018

Owen, S 2001, 'The practical, methodological and ethical dilemmas of conducting focus groups with vulnerable clients', Journal of Advanced Nursing, vol. 36, no. 5, pp. 652-8.

Paret, M 2015, 'Violence and democracy in South Africa's community protests', Review of African Political Economy, vol. 42, pp. 107-23.

Petrus, T \& Isaacs-Martin, W 2011, 'Reflections on violence and scapegoating in the strike and protest culture in South Africa', Africa Insight, vol. 41, pp. 49-61.

Pillow, W 2003, 'Confession, catharsis, or cure? Rethinking the uses of reflexivity as methodological power in qualitative research', International Journal of Qualitative Studies in Education, vol. 16, no. 2, pp. 175-96.

Pösö, T, Honkatukia, P, \& Nyqvist, L 2008, 'Focus groups and the study of violence', Qualitative Research, vol. 8, no. 1, pp. 73-89. doi:10.1177/1468794107085297

Potter, J \& Hepburn, A 2007, 'Discursive psychology: mind and reality in practice', in A Weatherall, BM Watson \& C Gallois (eds.), Language, discourse and social psychology, Palgrave MacMillan, New York, pp. 160-84. 
Potter, J \& Hepburn, A 2005, 'Qualitative interviews in psychology: problems and possibilities', Qualitative Research in Psychology, vol. 2, no. 4, pp. 281-307.

Potter, J \& Wetherell, M 1987, Discourse and social psychology: beyond attitudes and behaviour, Sage, London.

Puchta, C \& Potter, J 1999, 'Asking elaborate questions: focus groups and the management of spontaneity', Journal of Sociolinguistics, vol. 3, no. 3, pp. 314-35.

Rauch, J \& Storey, D 1998, The policing of public gatherings and demonstrations in South Africa, 1960-1994, Centre for the Study of Violence and Reconciliation, Johannesburg.

Robins, S 2014, 'Slow activism in fast times: reflections on the politics of media spectacles after apartheid', Journal of Southern African Studies, vol. 40, pp. 91-110.

Runciman, C 2017, 'South African social movements in the neoliberal age', in M Paret, C Runciman \& L Sinwell (eds.), Southern resistance in critical perspective: the politics of protest in South Africa's contentious democracy, Routledge, Oxford, pp. 36-52.

Saul, J 2014, 'The apartheid endgame, 1990-1994', in J Saul \& P Bond (eds.), South Africa the present as history: from Mrs Ples to Mandela and Marikana, Boydell and Brewer, Johannesburg, pp. 121-42.

Schneider, GE 2018, 'The post-apartheid development debacle in South Africa: how mainstream economics and the vested interests preserved apartheid economic structures', Journal of Economic Issues, vol. 52, no. 2, pp. 306-22.

Sinwell, L 2011, 'Is "another world" really possible? Re-examining counter-hegemonic forces in post-apartheid South Africa', Review of African Political Economy, vol. 38, pp. 61-76.

Socio-economic Rights Institute (SERI) 2014, Thembelihle: engaging an unresponsive state (Community Practice Notes Report No. 3), http://www.seri-sa.org/images/Thembelihle_ CPN_Final.pdf, Viewed date: 10 February 2018

South African History Online n.d., 'The June 16 Soweto Youth Uprising'. Accessed on 17 March 2018 from: https://www.sahistory.org.za/topic/june-16-soweto-youth-uprising

South African History Online n.d., 'Sharpeville Massacre, 21 March 1960' Accessed on 17 March 2018 from: https://www.sahistory.org.za/topic/sharpeville-massacre-21-march-1960

Underwood, M, Satterthwait, LD \& Bartlett, HP 2010, 'Reflexivity and minimization of the impact of age-cohort differences between researcher and research participants', Qualitative Health Research, vol. 20, no. 11, pp. 1585-95.

Von Holdt, K 2013a, 'South Africa: the transition to violent democracy', Review of African Political Economy, vol. 40, no. 138, pp. 589-604.

- 2013b, 'The violence of order, orders of violence: between Fanon and Bourdieu', Current Sociology, vol. 61, no. 2, pp. 112-31.

von Holdt, K, Langa, M, Molapo, S, Mogapi, N, Ngubeni, K, Dlamini, J \& Kirsten, A (eds.) 2011, The smoke that calls: insurgent citizenship, collective violence and the struggle for a place in the new South Africa: eight case studies of community protest and xenophobic violence, Centre for the Study of Violence and Reconciliation (CSVR) and Society, Work and Development Institute (SWOP), South Africa.

Wilkinson, S 1998a, 'Focus group methodology: a review', International Journal of Social Research Methodology, vol. 1, no. 3, pp. 181-203.

- 1998b, 'Focus groups in feminist research: power, interaction, and the co-construction of meaning', Women's Studies International Forum, vol. 21, no. 1, pp. 111-25.

Williams, R 1977, Marxism and literature, Oxford University Press, Oxford.

Woodring, JC, Foley, SM, Santoro Rado, G, Brown, KR \& Hamner, DM 2006, 'Focus groups and methodological reflections: conscientious flexibility in the field', Journal of Disability Policy Studies, vol. 16, no. 4, pp. 248-58. 